\title{
„Jako by mogli być wychowywani młodzieńcy, z których by potem byli słudzy Kościoła Bożego". O wychowaniu w domach ministrów i ordynowaniu na synodach Jednoty Braci Czeskich w Wielkopolsce
}

W każdym kościele niezmiernie ważne dla sprawnego funkcjonowania i zdobywania czy utrzymania wiernych jest przygotowanie duchownych. Nie inaczej było w przypadku Jednoty Braci Czeskich na terenie Wielkopolski. Początkowo funkcje duchownych sprawowali przybysze z Czech i Moraw, od lat siedemdziesiątych XVI wieku stopniowo przejmowali je Polacy. Związane to było przede wszystkim z systematycznym wzrostem liczby zborów, co pociagało konieczność obejmowania nowych przez kolejnych ministrów. Naturalną koleją rzeczy starzejących się, odchodzących lub umierających ministrów zastępowali młodsi, ukształtowani już na ziemiach polskich.

W 1560 roku polską prowincję Jednoty tworzyły trzy dystrykty: poznański, kaliski i kujawski, po 1573 roku powstał dystrykt sieradz$\mathrm{ki}$, a kaliski został podzielony na kaliski, koniński i pyzdrski. W latach 1587-1590 było około 35 zborów poświadczonych źródłowo, a na przełomie XVI i XVII wieku - co najmniej 50. Tak naprawdę nie wiadomo dokładnie, ile zborów działało w danym czasie (po części nie zachowały się żadne ślady, niektóre funkcjonowały bardzo krótko, istnienie innych jest niepewne). W każdym razie liczba zborów do pew- 
nego momentu stopniowo wzrastała $^{1}$, a do ich prowadzenia potrzebni byli duchowni, coraz mniej licznie przybywający z Czech i Moraw, gdyż również $\mathrm{w}$ ojczyźnie braci zaczynało ich brakować. W latach siedemdziesiątych XVI wieku zaczyna pojawiać się trochę więcej duchownych polskiego pochodzenia i byli to głównie młodzi ludzie wywodzący się ze stanu mieszczańskiego. Wymagania stawiane duchownym przez braci powodowały, że niełatwo znajdowali się chętni i nadający się kandydaci. Wielu z nich wywodziło się z rodzin ministrów i w ten sposób powstawały całe dynastie duchownych. Rzadko ordynowano ludzi spoza Jednoty, wstępujących do niej po zmianie wyznania. Polska Jednota, nie mogąc wychować wystarczającej grupy swoich duchownych, nad czym ubolewali kolejni seniorzy, domagała się od czeskich współbraci pomocy w tym zakresie ${ }^{2}$.

Przygotowanie duchownego określić trzeba jako trudne, długotrwałe i zmuszające przyszłego ministra do wielu wyrzeczeń i samodyscypliny. Ministrom wysoko stawiano poprzeczkę, dlatego wychowanie młodych musiało być tak ukierunkowane, aby w przyszłości sprostali najrozmaitszym żądaniom. Na stawiane na synodach pytanie: „Kto a jaki ma być minister ku temu urzędu godny?” odpowiadano „[...] < niechaj będzie wszelki minister bez skargi> i dalej rozwijano:

1) Aby na nas nie skarżyło sumnienie nasze, aby nie skarżyły owieczki, którym byśmy dosyć nie czynili, aby nie skarżył świat, że mu folgujemy; 2) niechaj będzie sprawiedliwy; 3) aby był święty; 4) dobrotliwy ku wszystkim owieczkam i ubogim nędznym; 5) opatrzny albo roztropny [...] opatrzny też w mowie, gdzie co mówić, i w pożywieniu swym etc.; 6) czujny; 7) trzeźwy; 8) powściągliwy, chociażby mógł czasem użyć wczasu swego, aby dla drugich, żeby im lepij służył, nie dospać etc.; 9) miarny w mowie, w karaniu, w domówkach etc.; 10) cierpliwy, umiejący znosić niedostatki i to, że mu się nie darzy, i niewdzięczność, aby się nie mścił na kazaniu etc., ale czekać czasu; 11) poważny, aby nie był żarterz, kunsztyrz; śmiechów, rozmów leda jakich nie wwodzić i nie pomagać; 12) doświadczony w wierze, życiu, cierpliwości; 13) uczciwy; 14) sposobny ku nauczaniu, żeby ludzie mogli pojąć, pilnie czując w nauce, mając tajemstwo wiary, żeby mógł i nauczać, i zwyciężać przeciwniki; 15) aby

1 Por. J. Dworzaczkowa, Bracia czescy w Wielkopolsce w XVI i XVII wieku, Warszawa 1997, s. 53.

2 Por. J. Bidlo, Wzajemne stosunki polskiej i czeskiej jednoty, „Reformacja w Polsce”, 1922, 2, s. 119. 
miał dobre świadectwo, żeby na nas zbór nie mógł skarżyć; na potwarzy niesprawiedliwe musimy nie dbać; 16) dobrze rządząc dom, nie zarazem fukać, trzaskać, ale pierwej znieść, nauczyć, cierpieć etc. Bo kto nie umie rządzić domu, żony, czeladzi, zamieszkiwa-li też modlitew domowych, wspominania, kazania etc. jakoż będzie insze owieczki rządził? Ku gościom uczciwy. Nie swowolny. Nie gniewliwy. Dla Pana gorlić, ale w rzeczach cielesnych nie unosić się z afektami. Nie swarliwy. Nie dwojakiego języka, aby nie było kłamstwo przy nas. Nie łakomiec. Nie żądościwy mierzionego podatku. Nie pijanica, zwłaszcza na tych biesiadach, na których mamy nieczęsto bywać, chyba żebyśmy rozumieli, że co zbudujemy. Nie przypijać jako świat. Nie bijca, z czeladzią etc., chyba dziatki różdżką, ale gdzie się z wielkim bić, mąż z żoną, z parobkiem etc. już to mizerna. Nie nowak. Przykładem wiernych w mowie, w obcowaniu etc. Naśladując sprawiedliwości etc. Bo[ju]jąc dobry bój, zachowując wiarę i dobre sumnienie, a Panu Bogu w tym się polecając. ${ }^{3}$

I nie były to tylko czcze rozważania i założenia, gdyż faktycznie dbano o to, aby duchowni spełniali te wymagania, a jeśli któryś wyłamywał się, surowo go napominano i karano. Problem przygotowania młodych do służby Jednocie pojawiał się często w trakcie obrad synodów i konwokacji. Zdawano sobie sprawę, że jeżeli Jednota nie będzie wychowywała młodych i zabiegała, aby zostali odpowiednio ukształtowani już w młodości, to może zabraknąć duchownych, co z kolei groziło odejściem wiernych i w rezultacie upadkiem.

W karierze duchownego Jednoty Braterskiej były trzy zasadnicze szczeble:

[...] trzy stopnie są sług Krystusowych: 1) akolutowie, przyjęci ku uczeniu się,

2) dyjakonowie, którzy już i insze uczą, 3) ministrowie, mając sobie zwierzone poselstwo Krystusowe, których bywają i starszy, inszym przełożeni. ${ }^{4}$

Minister mógł jeszcze zostać konseniorem czy seniorem. Uważano, iż najlepszą drogą kształtowania przyszłych duchownych jest wychowywanie ich w domach starszych, doświadczonych ministrów, najlepiej

3 Akta synodów różnowierczych w Polsce, t. IV: Wielkopolska 1569-1632, oprac. M. Sipayłło, Warszawa 1997, s. 44-45.

4 Ibidem, s. 52. 
seniorów5. I tak też starano się czynić. Przyszłego duchownego należało przyuczać od młodych lat, właściwie od dzieciństwa. Chłopca w wieku niekiedy około 10 lat oddawano do domów ministrów, a kiedy uznano, że nadaje się na duchownego, w wieku od 15 do 18 lat zostawał akolitą, kontynuował naukę i przygotowanie do czekających go zadań. Odpowiednia postawa moralna uchodziła za najważniejszą, ważniejszą nawet od wykształcenia. Jak przekonywano, właściwie uformować można przyszłego duchownego nie w szkole, ale właśnie w domach starszych, doświadczonych i zasłużonych dla Jednoty duchownych. Wiedza szkolna była w takim ujęciu czymś wtórnym, co nie znaczyło, że wśród duchownych Jednoty nie było ludzi wykształconych. Młodzież pobierała nauki w szkołach zborowych ${ }^{6}$, niekiedy kontynuowano edukację w dalej położonych placówkach: na Śląsku (Zgorzelec, Bytom Odrzański, Wrocław, Kożuchów, Głogów), w Prusach (Gdańsk, Toruń) lub udawano się na studia za granicę (do Altdorfu, Heidelbergu, Wittenbergi, Frankfurtu nad Odrą, Lipska, Strasburga, Genewy, Zurychu, Bazylei i innych ośrodków). Te wyjazdy umożliwiało wsparcie finansowe dobroczyńców albo Jednoty, która przyznawała stypendia uzdolnionym młodzieńcom ${ }^{7}$. Niekiedy młodzi, za zgodą starszyzny wyrażaną na synodach, towarzyszyli w zagranicznych wojażach synom szlacheckim i, korzystając z ich pobytu w ośrodkach uniwersyteckich, kontynuowali naukę. Ale edukacja szkolna, choćby w najlepszych ośrodkach, nie była najważniejsza. Nawet wykształcony w Wittenberdze Turnowski uważał, że studia uniwersyteckie nie są niezbędne, a najważniejsze $\mathrm{w}$ przygotowaniu duchownych jest wychowanie w domach braterskich ${ }^{8}$.

Starsi Jednoty namawiali ministrów do przyjmowania chłopców w celu wychowania ich na duchownych. Na synodzie w Poznaniu w 1578 roku Jerzy Izrael postulował:

5 Por. F. J. Zoubek, Vychováni a vyučováni v Jednotě bratrské, Praha 1883, s. 9; A. Molnar, Českobratrská výchova pred Komenským, Praha 1956.

${ }^{6}$ Por. D. Żołądź-Strzelczyk, Szkolnictwo Jednoty Braci Czeskich w Wielkopolsce, w: Ad novum fructum. Z okazji jubileuszu poznańskich historyków wychowania, red. W. Jamrożek, K. Ratajczak, D. Żołądź-Strzelczyk, Poznań 2007, s. 44-59; J. Dworzaczkowa, Szkota w Lesznie do 1656 roku. Nauczyciele i programy, Leszno 2003.

7 Por. D. Żołądź-Strzelczyk, Sprawy rodzinne, oświatowe i obyczajowe w Aktach Synodów Braci Czeskich w Wielkopolsce w XVI i XVII wieku, w: Spoteczeństwo staropolskie. Seria Nowa, t. III: Spoteczeństwo a rodzina, Warszawa 2011, s. 116 i n.

$8 \quad$ Por. J. Dworzaczkowa, Bracia czescy w Wielkopolsce..., s. 74. 
[...] abyście ucznie Boże przy sobie bawili a ony wychowywali [...] u ministrów po Czechach a Morawie, po kilku młodzieńców. Ale u was barzo po trosze. Br. Pietraszek jednego nam dał etc. inszy nie wiem by kto. Przetoż bracia naszego przykładu się trzymajcie. Jam wziął Eliasza w dziesiątym roku, Symeona w dwunastym. ${ }^{?}$

Wspierali go inni duchowni. Jan Lorenc zalecał, by „wziąć chłopca jakiego młodego a pomału ćwiczyć, aż się człowiek dochowa. Ma to tedy każdy z was pod sumnieniem swym na pieczy mieć, a snadź jeden od drugiego syna wziąć a ćwiczyć. Niech wżdy każdy ucznia jednego ma”. Szymon Turnowski mówił natomiast, że „wyćwiczenie a wypolerowanie ludzi młodych nie może być tak dobre przy nas, jako przy was, braci starszych, w więtszej czeladzi, tedy podobno tak być musi, ojcowie mili, żebyśmy my wam słali podlejsze, a od was brali lepsze" ${ }^{10}$. A zatem, ministrowie powinni nawzajem brać swoich synów na wychowanie, a najlepiej jeżeli młodzi przebywać będą w domach seniorów. Izrael odwoływał się do dawnego obyczaju jeszcze z ojczyzny braci: zalecał, aby naśladować to, co się dzieje w Czechach i na Morawach, gdzie ministrowie wychowują po kilku młodzieńców, a w Polsce „barzo po trosze", a Lorenc nawiązywał do tradycji jeszcze starszej, bo biblijnej, gdyż wspominał uczniów towarzyszących Chrystusowi i naśladujących Mistrza ${ }^{11}$. Izrael wypomniał ministrom, że nawet jeżeli któryś ma w domu na wychowaniu młodzieńca, to często „oni, hned pobywszy czwerć roku, piszą, prosząc, abyśmy je wzięli. Co się snadź dzieje dla waszego niesposobu w wychowywaniu i opatrywaniu potrzebami należącymi etc." ${ }^{2}$ Izraela poparł Jan Lorenc, podkreślając, iż należy do powierzonego sobie młodzieńca podchodzić tak, aby „ku tobie miał miłość, [a] za tym pójdzie wszystko dobre".

W ojczyźnie braci chłopców przygotowywano do zawodu duchownego w domach biskupów, gdzie gromadzili się licznie ministrowie, diakoni i młodzieńcy. Te tzw. „domy braterskie” były swego rodzaju szkołami przygotowującymi chłopców od najmłodszych lat do wypełniania obowiązków duchownego. W takich „domach braterskich” mieszkało kilkanaście, nieraz kilkadziesiąt osób: chłopców, akolitów, diakonów, ministrów, oczekujących na swój pierwszy zbór, no i, oczywiście, mini-

9 Akta synodów różnowierczych w Polsce, t. IV, s. 52-53.

10 Ibidem, s. 53.

11 Ibidem, s. 51-52.

12 Ibidem, s. 53. 
ster czy senior i jego rodzina. Stąd ważne było uposażenie takich zborów. Należały do nich często ogrody, warsztaty, w których praktykowali akolici i diakoni. Przyszłych duchownych wdrażano również do pracy fizycznej, uczono rzemiosła, np. tkactwa ${ }^{13}$. Takie „domy braterskie” znajdowały się, m.in. w miejscowościach Ivančice i Mladá Boleslav ${ }^{14}$ i około 1570 roku były to najbardziej znane placówki tego typu. W pierwszej młodzi wychowywali się w „czeladce” biskupa Jednoty - Jana Augusta, w drugim - Jana Blahoslava. Podobne domy mieli inni duchowni, ale nie były one tak liczne i ważne, jak wymienione wyżej. Blahoslav stworzył nawet traktat o wychowaniu młodzieńców do służby Bożej właśnie $\mathrm{w}$ domu seniorów ${ }^{15}$ i w dziele swym prawdopodobnie opisał własne doświadczenia na tym polu.

W Polsce właściwie nie było takich „edukacyjnych dworów”, jedynie dom seniorów w Ostrorogu mógł przez pewien czas pełnić podobną funkcję i prawdopodobnie przypominał czeskie „domy braterskie”. Kolejni seniorzy mieszkający w Ostrorogu (Izrael, Lorenc, a potem Turnowski) przyjmowali chłopców na wychowanie. Przebywali u nich chłopcy, akolici, diakoni, a także przynajmniej jeden minister wspomagający seniora w wykonywaniu jego obowiązków w zborze, kiedy ten był zajęty sprawami Jednoty. W domu seniora mogli rezydować również samotni, starzy ministrowie po zakończeniu pracy dla Jednoty.

Szymon Teofil Turnowski, urodzony w 1544 roku, w wieku czterech lat z rodzicami przywędrował do Polski. W 1557 roku przyjął go na wychowanie do swego domu w Ostrorogu Jerzy Izrael (o czym wspomniał podczas obrad synodu w 1578 roku). Akolitą i diakonem został Turnowski w 1569 roku, ministrem — w 1573 roku $^{16}$. Pełnił funkcje: konseniora wielkopolskiego (1583), seniora (w $1587 \mathrm{roku}$ ) i ministra w Ostrorogu, gdzie kontynuował dzieło Izraela i przyjmował na wychowanie młodzieńców. Bywało, że w jego domu uczyło się dwunastu chłopców. W 1608 roku, kiedy zmarł, zamieszkiwało tam trzech mło-

13 Por. J. Dworzaczkowa, Sytuacja materialna duchowienstwa braci czeskich $w$ Polsce do początków XVII wieku, w: Ead., Reformacja i kontrreformacja w Wielkopolsce, Poznań 1995, s. 189.

14 Por. J. Bidlo, Jednota bratrská v privním vyhnanstvi, t. III: 1572-1586, Praga 1909, s. $96 \mathrm{i} \mathrm{n.}$

15 Por. J. Blahoslav, Naučeni mládencuim k službě Kristu a církvi jeho se oddávajícím v Jednotě bratrské, wyd. Fr. Bednář, Kalich-Praha 1947.

16 Por. Akta synodów różnowierczych w Polsce, t. IV, s. 16. 
dzieńców i sześciu chłopców. W aktach konwokacji, która odbyła się już po pogrzebie Turnowskiego w czerwcu 1608 roku, czytamy, między innymi, o tym, że rozmawiano z „chłopięty domowymi”, aby poznać ich plany i zamierzenia na przyszłość. W otoczeniu zmarłego seniora, jak wynika z zapisków, przebywało wtedy co najmniej sześciu chłopców. Część z nich chciała zostać rzemieślnikami, a część planowała uczyć się dalej:

Mówiło się z chłopięty domowymi: Jakubek chce na rzemiosło, Tobiasz obiecuje słuchać br. starszych, na co dał rękę. Tobiasz dla doświadczenia dalszego na czas ma być do br. Macieja Paszkowskiego dany. Jadamek woli na rzemiesło niż do szkoły, tego na czas wziął do siebie br. Jan Pietraszek. Matyjasz Michalczyk opowiada się z chęcią do nauki i z posłuszeństwem; naznaczony br. J. Turnowskiemu. Ioannes Węgierski pod trzy lata uczył się w Bytoniu; chce słuchać i ćwiczyć się do służby Bożej. Ma trwać w Ostrorogu do synodu, w szkole pomagać, sam się też ćwicząc. Matyjaszek Białego posłuszeństwo obiecał i ćwiczyć się w nauce. Zostawion w Ostrorogu na dalszy czas. ${ }^{17}$

Było tam również trzech akolitów: Kasper, Ambroży i Mikołaj. Polecono im, „aby trwając w posłuszeństwie świętym, zgodnie w miłości braterskiej z sobą mieszkali, powinności sobie zlecone wiernie odprawowali, a br. Pawłowi [wyznaczonemu do zarządzania domem zmarłego] powolni we wszem byli. Które napominanie oni wdzięcznie przyjęli, powolność wszelką przyrzekłszy"18.

Właśnie w Ostrorogu w 1602 roku napisał Turnowski wskazówki w języku polskim, dostosowane do polskich realiów i nawiązujące do opublikowanego w Kralicach w 1585 roku traktatu Jana Blahoslava z zaleceniami dla przyszłych duchownych. Wcześniej takie instrukcje opracował, a być może również spisał, Jerzy Izrael dla potrzeb „czeladki” przebywającej w małopolskim Seceminie w siedzibie Feliksa Crucigera, superintendenta kościoła kalwińskiego. Rady te mogły stanowić jedno ze źródeł utworu Turnowskiego ${ }^{19}$.

\footnotetext{
17 Ibidem, s. 189.

18 Ibidem, s. 191.

19 Por. J. Bidlo, Jednota bratrská v privnim vyhnanstvi, t. I: 1548-1561, Praga 1900, s. $156-157$.
} 
Ten tzw. Traktacik uczniowski, znajdujący się obecnie w zbiorach Biblioteki Raczyńskich w Poznaniu ${ }^{20}$, został przedstawiony na synodzie w Koźminku w 1602 roku i tam nad nim dyskutowano:

[...] br. Symeon z czeskiego przełożył a dokładniej napisał i na tym synodzie pro concione wszystkim przeczytał, będzie od br. Symeona bracij starszym ku przejrzeniu podany, żeby każdy z nich na karcie poznaczył zdanie swoje porządnie a br. Symeonowi odesłał. A zostało-li-by co in controversia, za spólnym zgromadzeniem żeby collatione rationum skończone było. ${ }^{21}$

Bracia chcieli, czemu także dali wyraz na tym synodzie, „żeby [traktat] był publikowany".

Dzieło składa się z dwóch zasadniczych części: „w pierwszej zamykają się nauki potrzebne uczniom początecznym, a w drugiej należące już wzrost biorącym a na wyższe stopnie w Bożym domu postępującym" ${ }^{22}$. Na początku przedstawiono warunki, jakie należało spełnić, aby proces przygotowywania młodych do służby dla Jednoty przebiegał prawidłowo. Młodzi powinni mieszkać „przy sługach Chrystusowych” i w traktacie dokładnie określono wzajemne relacje mistrzów i wychowanków. Młodzi mają przebywać „Nie jako dworzanie a słudzy u Panów abo jako najemnicy na robocie u gospodarzów dla myta a pożytku cielesnego a dla jakiej wysługi i zgromadzenia sobie dóbr ziemskich", ale również „Nie jako goście a obcy dla zażywania a rozkoszowania bez prace abo jako mniszy w klasztorze żeby próżniąc tylko kałdony swe tuczyli”. Natomiast „mieszkać mają przy Starszych swych sługach Chrystusowych jako cnotliwi a życzliwi synowie przy ojcach miłych a uczniowie pilni przy swych nauczycielach a wodzach”. Ważne jest, że „przy sługach Bożych przełożonych swych mieszkać ma [kandydat na duchownego] nie w ten sposób, aby żył i uczył się według woli a zdania swego, ale posłusznie a dowiernie wszystko żeby czynił a rządził się według woli rady a zlecenia przełożonych swych" 23 .

20 Por. S. T. Turnowski, Traktacik uczniów Chrystusowych, egz. Biblioteki Raczyńskich w Poznaniu (sygn. 47).

21 Akta synodów różnowierczych w Polsce, t. IV, s. 176.

22 S. T. Turnowski, Przedmowa, w: Id., Traktacik, s. 26. Transkrypcję fragmentów dzieła Turnowskiego sporządziła Autorka artykułu.

23 Ibidem, s. 27. 
Następnie Turnowski przechodzi do omówienia powodów, dla których młodzi powinni mieszkać przy starszych i bardziej doświadczonych. Po pierwsze, będą mieli „lepsze przyczyny i więtszą pomoc do zbawienia swego, i wzrostu a pomnożenia i zachowania w nim". Mieszkanie wspólnie ze starszymi jest w pewnym sensie naśladowaniem Chrystusa i apostołów, Chrystus bowiem swoich towarzyszy „z świata wybrał a sobie odłączył i przy sobie ćwiczył w służbie Bożej a skutkach świętej pobożności”. Podobnie, przebywanie ze starszymi powoduje, że młodzi „bezpieczniejszymi byli o pokus szatańskich, które pobudza z tymi przyczynami, mowami, wnętami i przykładami niezbożnego świata”. Młodzi mają żyć w domach starszych „dla nabywania światłości a umienia mądrości Bożej w znajomości Pana Boga a woli i dróg a skutkow jego”. Wspólne mieszkanie umożliwia także słuchanie „napominań każdodziennych rozmów o Panie Boże a drogach jego". Z drugiej strony, „służebnikom a posłom Chrystusowym w Cerkwi jego, a tak w nich samemu Panu Jezusowi służąc i w rzeczach doczesnych a pożywieniu należących pomagając, a brzemienia frasunków i prac ich im ujmując” mogą zasłużyć na „łaskę a błogosławieństwo Boże”. Przygotowując się do pracy duszpasterskiej młodzieńcy mają, „przy starszych swych mieszkając a zaraz z młodu się pilnie przypatrując”, uczyć się od nich „sposobów, obyczajów, a umiejętności dzieła Bożego i wykonywania prac a powinnością urzędu świętego: żeby wiedzieli a umieli na wszytki strony jako gdzie potrzeba postępować, a jako co ku budowaniu Kościoła Bożego roztropnie a pożytecznie działać”. Turnowski zdawał sobie sprawę, że „nie ze wszystkich młodzieńców u Braci mieszkających będą przedniejsi kaznodzieje w domu Bożym sprawcowie, a jako tarcze przeciw nieprzyjaciołom" ${ }^{24}$.

Kolejna kwestia podniesiona przez Turnowskiego wiązała się z tym, „czego uczniom Christusowym do pożytecznego uczenia się potrzeba?”. Przede wszystkim „potrzeba im uprzejmej chęci do nauki a ćwiczenia się w mądrości Bożej, tak strony zbawienia swego a służby Bożej, jako też strony służenia przełożonym i Kościołowi Bożemu, żeby sobie pochutnywali a kochali się w każdej świętej pracy”. Dalej,

[...] potrzeba uczniom Chrystusowym szczerze a dowiernie przyjmować nauki i napominania od przełożonego swojego, trzeba uczniom prostego oka

24 Ibidem, s. 29. 
umysłu szczerego, żeby się przy sługach Chrystusowych uczyć chcieli naprzód dla wzrostu w swoim własnym zbawieniu. [...] Potrzeba też uczniom nie górnej myśli być, żeby przełożonemu swemu i każdemu z towarzystwa wolność a prawo nad sobą dali do upominania i strofowania a odwodzenia od złego i do ćwiczenia potrzebnego. A żeby się nie sromali pytać się o tym, czego nie umieją a nie wiedzą. Bo uczyć się nie jest sromota [...] Trzeba też uczniom nie spuszczać się na swoję pamięć, ale pilnie sobie i namniejsze sztuczki od starszych z grontu pisma $S$. a smysłu i rozumu zdrowego podawane nie tylko na kazaniach, lecz i przy rozmowach a rozwięzowaniu te zapisować. [...] Potrzeba uczniom doświadczenia. [...] Potrzeba też uczniom modlitw świętych a duszliwych, żeby Pan Bóg ducha a serdce i wszystek żywot ich zposobować raczył, chętnie czynić do ćwiczenia się potrzebnego i w pracy żeby błogo sławił. ${ }^{25}$

Wreszcie traktacik podaje, czego młodzi powinni się uczyć. W 35 punktach ujęto „powinności Bożych uczniów, w których owszem diakonowie i ministrowie mają się obficiej znajdować". Są to, przede wszystkim, zalecenia odnoszące się do kształtowania charakteru i obyczajów, mniej umysłu.

Młodzi muszą więc poznawać podstawy wiary, czytać Pismo Święte, studiować katechizm, księgi i traktaty braterskie („nabywać, przepisywać sobie i czytać”). Z nauk „szkolnych” winni przyswoić sobie gramatykę łacińską, umiejętność „dobrego i czytelnego pisania”. Ponadto, trzeba ćwiczyć ich w cierpliwości, skromności, pilności, służeniu innym, dobrym zachowaniu, porządku, znoszeniu niedostatków, pomaganiu przełożonym, wierności, unikaniu złego towarzystwa. Jak widać, konsekwentnie na pierwszy plan, obok wychowania religijnego, wysuwano wychowanie moralne i kształtowanie obyczajów. To nie wiedza szkolna, jak czytamy u Turnowskiego, jest najważniejsza i formuje człowieka, liczy się bowiem jego sylwetka moralna. To ona stanowi podstawę i decyduje o tym, czy ktoś nadaje się do służenia innymi. Dlatego też tak ważne było edukowanie człowieka nie w szkole, ale właśnie w domu ministra czy, jeszcze lepiej, seniora. Autor traktatu zwrócił również uwagę na konieczność pracy fizycznej („cielesnej”) w gospodarstwie ${ }^{26}$.

25 Ibidem, s. 32-33.

26 Ibidem, s. 34-36. 
Między pierwszą a drugą częścią traktatu znajduje się wierszowane podsumowanie Rząd mtodzieńców mięszkających przy stużebnikach Bożych w domiech Jednoty Braterskiej ${ }^{27}$.

Druga część zawiera zalecenia dla osób bardziej zaawansowanych w naukach i przygotowaniach do służby Bożej, czyli dla akolitów, diakonów, młodych ministrów. Wskazówki te podzielono na 13 artykułów:

1. Stopnie zbawienne w których się zamyka prawda Chrześcijaństwa a tajemnica wiary ku dostąpieniu żywota wiecznego.

2. Umiejętność a zmysł zdrowy przy tej prawdzie a stopniach zbawiennych.

3. Ćwiczenie się w Piśmie S. i w pieśniach a psalmiech.

4. Wiadomość stopniów przełożeństwa, $\mathrm{z}$ przestrzeganiem rządu a posłuszeństwa.

5. Sposób a obyczaje sługi Chrystusowego w Kościele jego.

6. Czytanie i mówienie a kazanie we zborze.

7. Pasterska umiejętność w usługowaniu kazaniem słowa Bożego pożytecznym ludziom.

8. Powinności diakonów.

9. Powinności ministrów młodych.

10. Kanony Apostolskie o powinnościach i cnotach a znakach prawdziwego służebnika Chrystusowego w Cerkwi jego.

11. O stanie Panickim w czystości Ducha i ciała.

12. O porządnym wstępowaniu w stan małżenski.

13. Sententia[e?] ludzi mądrych z naukami o żywocie pobożnym. ${ }^{28}$

Powyższe zalecenia zostały omówione starannie i wyczerpująco. Znajdujemy wśród nich, między innymi, rady dotyczące „mówienia i kazania we zborze”. Obok umiejętności czytania „bez syllabizowania albo zająkania a zacinania się”, Turnowski kładł nacisk na „miarkowanie głosu według potrzeby”, staranną wymowę, modulowanie głosu. Przestrzegał, „żeby się młodszy nie sromał przed starszymi, gdy mu bywa zlecono mówić, a od onych i drugich Braci strofowania, przestrogę, napomnienia i ćwiczenia potrzebnego ku umiejętniejszemu kazaniu, przyjmować" 29 .

27 Ibidem, s. 37-38.

28 Ibidem, s. 40.

29 Ibidem, s. 48 i n. 
Po spaleniu Ostroroga jeden z dwóch seniorów wielkopolskiej Jednoty mieszkał w Lesznie, drugi natomiast $\mathrm{w}$ innym zborze, między innymi, w Karminie. Przebywali tam, pełniący funkcję seniorów, Marcin Orminiusz i Jan Bytner - ostatni minister tego zboru. W domu Bytnera znajdowała się grupa uczniów i ministrowie zastępujący seniora w wypełnianiu obowiązków zborowych podczas jego podróży w sprawach Jednoty ${ }^{30}$.

Problem wychowania kolejnych pokoleń duchownych pojawiał się wielokrotnie w trakcie obrad synodów zarówno w XVI, jak i w XVII wieku. Na synodzie w Stawiszynie w maju 1586 roku zastanawiano się „nad tym, jak zabieżeć niedostatkom Kościoła Bożego barzo od wszystkich zaniedbanego". Za jedną z najważniejszych spraw uznano właśnie przyjmowanie do domów „starszych braciej a ministrów” na naukę i wychowanie „młodzieńców i dziatki ubogich, z których by potem byli słudzy Kościoła Bożego" ${ }^{31}$. W 1600 roku na synodzie w Gołuchowie przypominano ministrom, „żeby młodzieńce przy sobie wychowując te, którzy się w posłuszeństwo oddali, z synów Jednoty nie czynili najemników a nie postępowali im pewnego stypendium, ale jako ojcowie syny wszystkimi potrzebami według przemożenia opatrowali” i odwrotnie młodzieńcy nie powinni z siebie czynić najemników, ale „przykładem Chrystusowych, prorockich i apostolskich uczniów przez starszych swych żyli”32.

Z czasem liczba zborów już się nie powiększała, a wręcz przeciwnie - malała, ale to nie znaczyło wcale, że Jednota dysponowała dostatecznie liczną grupą duchownych. Wysokie wymagania stawiane przed nimi z jednej strony, z drugiej zaś brak niekiedy wystarczających środków do życia, powodowały, że trudno było o kandydatów. Duchowni Jednoty nie mogli „dorabiać” i wykonywać innych prac. Nie wolno im było, między innymi, produkować trunków na sprzedaż czy nabywać nieruchomości. W najlepszej sytuacji materialnej znajdowali się stosunkowo nieliczni seniorzy, lecz dojście do takiego stanowiska zajmowało sporo czasu wypełnionego nienaganną pracą ${ }^{33}$. Niepewna była również sytuacja duchownych w społeczeństwie polskim, ich los niejednokrot-

30 Por. J. Dworzaczkowa, Zbór braci czeskich w Karminie, w: Ead., Reformacja i kontrreformacja..., s. 163-164.

31 Akta synodów różnowierczych w Polsce, t. IV, s. 90.

32 Ibidem, s. 163.

33 Por. J. Dworzaczkowa, Bracia czescy..., s. 142. 
nie zależał od woli szlachty. Z czasem głównie synowie ministrów zostawali ministrami. W ten sposób pojawiło się kilka pokoleń duchownych wywodzących się z jednego rodu: Orliczowie, Rybińscy, Chodowieccy, Musoniusowie czy Kassjuszowie.

W XVII wieku młodzieńcy, którzy chcieli poświęcić się pracy dla Jednoty, nadal oddawani byli do domów seniorów i ministrów. Na wielu synodach poruszano ten problem. W 1633 roku na synodzie w Ostrorogu zastanawiano się, co zrobić, „żeby na sługach Bożych godnych w Jednocie nie zchodziło” i wskazywano drogę, by „przy ministrach wychowywani byli ludzie młodzi”. Kilku ministrów zobowiązało się przyjąć do swego domu młodzieńców („po diakonie i jednym chłopięciu”) ${ }^{34}$. Rok później zastrzeżono, aby

[...] nie bywali dani do szlachty i mieszczan dla sztuki chleba, ale raczej przy starszych i ministrach pod rządem chowani i ćwiczeni byli. [...] A jeśliby którzy na condicie mieli być dani, aby tylko pokorniejsi a w cnotach doświadczeni do tego przypuszczeni byli, wszakże i ci żeby do inspekcej conseniorów i ministrów tak należeli, jakoby własnymi domownikami ich byli. ${ }^{35}$

Podkreślano, że nie każdy minister nadaje się do sprawowania pieczy nad młodymi. Zalecano nie spieszyć się zbytnio z ordynowaniem, a czynić to „dopiero wtenczas, gdyby [kandydat] w nauce dostatecznie był wyćwiczony, w pobożności doświadczony i w rządzie Jednoty był utwierdzony" 36 .

Ponieważ utrzymanie jednego lub kilku młodzieńców stanowiło znaczące obciążenie dla ministra i jego gospodarstwa, w 1654 roku uchwalono, że ministrowie mają prawo do otrzymywania wynagrodzenia z ogólnej kasy:

Kiedy którykolwiek z braciej młodzienia dla pomocy swej chowa, tego też sam nie spodziewając się ani upominając nijakiej do starszych zapłaty od niego żywić powin. Od tych zaś którychby nad potrzebę swoję X. Senior albo więc kto inszy chował, powinno się będzie płacić ex publico. ${ }^{37}$

34 Synod w Ostrorogu 1633, Archiwum Państwowe w Poznaniu (dalej APP), sygn. 1490 .

35 Synod w Ostrorogu 1634, APP, sygn. 1493.

36 Ibidem.

37 Synod w Lesznie 1644, APP, sygn. 1517. 
Jak wspomniano wyżej, kandydat na ministra przechodził kolejno kilka szczebli: najpierw zostawał akolitą, potem diakonem i wreszcie mógł zostać ordynowany na ministra. Pokonywanie kolejnych etapów, po latach nauki i przygotowań, odbywało się na synodach. Starsi Jednoty egzaminowali młodych i decydowali, kto nadaje się, aby iść dalej, a kto jeszcze musi się uczyć. Motywowali ich także do pilniejszego kształcenia się.

Na synodach, niestety nie wszystkich, ordynowano nowych duchownych lub kandydatów na duchownych — akolitów, ale nie było ich zbyt wielu, co martwiło seniorów. Na synodzie w Poznaniu w czerwcu 1569 roku przedstawiono Powinności akolitów:

1. Po księżej i dyjakoniech powinności aby sprawowali, a na nie słuchali.

2. Cokolwiek starszy rozkażą, czynili. Katechizmu i Spisku uczelnieckiemu się uczyli.

3. Co się kolwiek od starszych przypisować, w tym iżby wierność zachowywali.

4. Pilnie czytać Pisma św., smysłu albo rozumienia zdrowego nabywać, rozumieć, pamiętać ośmioro błogosławieństwa.

5. Poczynające katechizmu uczyć.

6. Pisma św. w zborze czytać, gdy starszy rozkażą.

7. Zbór albo kościół umietać, miesce ku siedzeniu słuchaczom, gdzie trzeba, gotować.

8. Księżej i dyjakonom służyć wodą do krztu i inszymi rzeczami poświątnymi.

9. Dyjakonom gotowi a posłuszni być. Rzeczy ku pożywieniu należące pilnie sprawować.

10. Poselstwo wiernie wykonywać.

11. Gościam służy. Braciej nogi umywać etc.

12. Dyjakonów pomocnikami być, w ich powinnościach to retować i zastępować, gdzie by ich nie było. ${ }^{38}$

Na synodzie w 1580 roku w Poznaniu, kiedy ordynowano dwóch diakonów - Mateusza Maja i Mateusza z Lutomierska — zaprezentowano z kolei „powinności” diakońskie. Diakon miał więc obowiązek:

38 Akta synodów różnowierczych w Polsce, t. IV, s. 3-4. 
1) Pomagać pastyrzom prace ich służbą i przykładem; 2) kazać słowo Boże, gdzie posłani będziecie od starszego; 3) członkom Kościoła Bożego się przypatrywać, mieć je wszystki naznaczone na regestrze, znać je, napominać, starszemu odnajmować; 4) miesce w zgromadzeniu i rzeczy ku służbie Bożej, chleb etc. gotować; 5) krztem i ślubem służyć; 6) wyłączone za rozkazaniem pasterza wywodzić a oddalać; 7) dziatki krześcijańskie mieć na pieczy, czwiczyć; 8) z sędziami pracować w potrzebach Kościoła Bożego; 9) przy starszym bywać, służyć mu doma i w drodze we wszystkim.

Druga część obejmowała następujące zobowiązania:

[...] w domu pieczować o ty, co w domu są; usługować czeladzi Bożej; zatem w rzeczach a potrzebach tych cielesnych zgromadzaniu i szafowaniu imi, a gdy czas zniesie, pracować i rękoma swymi; pieczować o ludzie ubogie, aby byli opatrywani za ich dojrzeniem. ${ }^{39}$

$\mathrm{Na}$ tym samym synodzie ordynowano na ministrów Szymona Musoniusa, Marcina Sieradzkiego, Jana Bełdowskiego. Otrzymali oni uprawnienia ministerialne, a mianowicie: 1) „kazać”; 2) „kluczy Krystusowych używać”; 3) „sąd jego sprawować a wyłączać złe”; 4) „sakramentami szafować”; 5) „modlić się za ludzi”; 6) „przykładem dobrym służyć; o ubogie pieczołować etc." ${ }^{40}$

Podczas synodu w Poznaniu w 1580 roku wyświęcono więc zaledwie dwóch diakonów i trzech ministrów. Nie zawsze było tak niewielu, ale zdarzały się synody, podczas których wyznaczano mniejszą liczbę duchownych. Nie najgorzej wyglądała sprawa ordynowania akolitów — niekiedy ordynowano kilka osób, ale bywało, że nawet 24, jak na synodzie w 1632 roku. Gorzej działo się z diakonami, chociaż trafiały się lata, kiedy ordynowano 7, 8 czy nawet 9 osób. Najmniej wyświęcano ministrów. Najwięcej, bo 5 osób, ordynowano w latach 1571, 1575, 1609 i 1652, ale bywały okresy, kiedy nie wyświęcono żadnych ministrów. Jest to zrozumiałe, ponieważ w trakcie przygotowań odchodziły osoby nie do końca zdecydowane, takie, którym służba ministra wydała się zbyt ciężka, stąd ta malejąca liczba przekraczających poszczególne szczeble „wtajemniczenia”.

39 Ibidem, s. 66.

40 Ibidem, s. 66-67. 
Na synodzie w Lesznie w 1652 roku odbyło się takie „przechodzenie” młodych z niższego stopnia na wyższy. Najpierw starsi „młódź, która się in spem Ecclesiae chowa przedsię wziąwszy examinowali, i do pilniejszego się ćwiczenia w rzeczach do przedsięwzięcia ich służących, upomnieli”. Następnie, „po południu, byli przed Br. Starszą br. diaconowie i insza młódź z chłopcami zwołani. Gdzie dano im do przeczytania kazanie X. Wacława Lochała, które miał na synodzie leszczyńskim Ao. 1647 dla Acolutów”. Najpierw egzaminowano młodszych chłopców: „z młodszemi się zabawiali pytając się wprzód na lata ich", ale nie wszystkim udało się dobrze wypaść. Część z nich „odłączono [...] i ordinatia ich na dalszy czas odłożono, dawszy im napomnienie aby posłuszeństwo wszelakie Starszym oddawali, a żeby się Pana Boga bojąc pilno w naukach ćwiczyli. Co daniem prawicy swej oni ślubili i potwierdzili”. Po modlitwie odbyło się ordynowanie akolitów. Jak wcześniej podano, bracia starsi pytali młodzieńców, ile mieli lat, stąd wiemy,w jakim wieku zostawali akolitami (chłopcy osiągnęli wiek od 15 do 19 lat). Kolejnego dnia „brat Starszy rejestrzyk starszych acolutów braciom ministrom podali, aby obaczyli, którzyby z nich do urzędu diakońskiego sposobnemi byli. Podług którego rejestru wszyscy byli examinowani w kole ministrowskim [...], po examinie ich bracia ministrowie, dobre świadectwo i zalecenie dali B. Adamowi Hartmanowi i B. Pawłowi Hartmanowi, i żeby im gradue Diaconatus był zlecony upraszali. Inszych ordinatia, aby do inszego czasu była odłożona, radzili”. Jednego z braci, niejakiego Jana Köchlina, „wymazano” z rejestru akolitów. „Po kazaniu był akt ordynowania diaconów. Ordinator był X. Senior Bithner”¹. W sobotę, 19 października, „po modlitwie [...] zeszli się bracia ministrowie [...] dla examinowania kandydatów ministerij”. Po egzaminie i kazaniu „była ordinatia braci ministrów” ${ }^{2}$.

Nie wszystkich też dopuszczano na wyższe stopnie. Mimo iż Jednota nigdy nie miała zbyt wielu duchownych, to jednak nie starano się ich ordynować za wszelką cenę. Nie wyświęcano na wyższe „stopnie” zbyt młodych ludzi, jak to, na przykład, miało miejsce na synodzie w 1652 roku, kiedy bracia „przypomnieli, że się jeszcze zda zbyt młodym [jeden z kandydatów], by stąd nie urosło zgorszenie, jakoby chłopięta na diakoństwo przyjmowali”. Zanotowano również inne przypadki braku zgody na

41 Synod w Lesznie 1652, APP, sygn. 1514.

42 Ibidem. 
przechodzenie na wyższe szczeble kariery braterskiej. Na synodzie w 1640 roku diakon Augustyn Claudian, akolita od 1634 roku, „examinowan był Inter ordinandos ad ministerium, ale że się jeszcze nie takowe wiadomość i umiejętność pism świętych przy nim znajduje, jaka ma być sług bożych w Kościele, do dalszego czasu ordynowanie jego odłożono i poruczono mu to, aby się cale na czytanie Pism Św. udał. Gdy się lepszy w nim profect a przy tym i potrzeba pokaże, aby był ordynowany i bez synodu, na co ministrowie consens swój dali” ${ }^{43}$. W przytoczonym fragmencie mamy ciekawą informację o tym, że ordynowanie mogło się odbywać także poza synodami, jeżeli tylko ministrowie wyrazili na to zgodę. Claudian został ministrem jeszcze w tym samym roku, na synodzie w Lesznie.

Troska starszych o jak najlepsze wychowanie młodych i oddawanie ich do domów ministrów czy seniorów nie zawsze wychodziła na dobre, ministrowie bowiem mieli żony i córki. Powierzeni ich opiece młodzieńcy żyli z nimi oraz z ich rodzinami pod jednym dachem. Niestety, czasami kończyło się to skandalem. Takie sprawy poruszano także na synodach i tak było, między innymi, w 1640 roku. Ordynowany w 1632 roku na akolitę Samuel Chryzostom miał w 1640 roku zostać „poczczony urzędem diakońskim i miejscem potrzebnym”. Jednak mimo iż był „młodzieńcem pięknymi darami bożymi obdarzonym”, „grzechem wszetecznym” „się [...] splugawił i urzędu w kościele Bożym niegodnym uczynił”. Z opisu wywnioskować można, że dopuścił się cudzołóstwa z córką ministra Wacława Tita. Jego także zganiono, ponieważ „niedbały był w doglądaniu domu swego”. Sprawę rozwiązano w następujący sposób: młodzian musiał poślubić dziewczynę i odbyć pokutę. Na szczęście dla niego starsi uznali, że nawet grzesznikowi należy się łaska i „jeżeli będzie prawdziwie pokutował i za grzech swój żałował", to będzie miał szansę na zostanie ministrem ${ }^{44}$.

Duchownego w Jednocie Braci Czeskich wychowywano długo i starannie. Nie wiemy, niestety, ilu młodzieńców przebywało w domach braterskich ani ilu z nich zdecydowało się na kontynuowanie przygotowań i zostanie duchownym. Nie wszystkim, którzy, trafiając do domów ministrów czy seniorów, zaczynali przygotowanie do służby w kościele, dane było dotrwać do momentu ordynowania na ministra. Liczba ministrów zawsze była mniejsza niż diakonów czy akolitów: w latach

43 Synod 1640 w Skokach, APP, sygn. 1594.

44 Konwokacja w Lesznie 1640 r., APP, sygn. 1594. 
1571-1652 ordynowano 150 akolitów, 74 diakonów, a tylko 58 ministrów. Przyczyny tego były zapewne różne. $Z$ jednej strony młodzieńcy nie decydowali się na trudne życie duchownego i wybierali inną drogę, z drugiej starszyzna nie wszystkich dopuszczała do ordynowania, nakazując dalszą naukę lub całkowicie rezygnując z niektórych kandydatów, uznając ich za niegodnych pełnienia funkcji duchownego.

\section{"How to Educate Youth so that They will later become Servants of the Church of God". Referring to Education in the Homes of Ministers and the Ordained in the Synods of The Unity of the Brethren in Greater Poland}

The article discusses the preparation of the clergy of The Unity of the Brethren in Greater Poland. The best way of education was considered to be the tuition of boys in the homes of ministers and high ranking citizens. It was regarded as far more important than a school education. This method was recommended, with regard to the customs in force in the country, by the elders of the Brethren, who took adolescents into their homes to educate them. The ways in which to shape the future clergy was advised by the synods. Guidance in this area was developed by Szymon Turnowski, who adapted Jan Blahoslava's tractate to Polish conditions. Acolytes, deacons and ministers were also ordained at the synods. The academic requirements for the clergy were high and for this reason, despite their own interventions, the sect was often lacking in ministers. The struggle of educating the clergy was one of the most serious problems faced by the Brethren. 